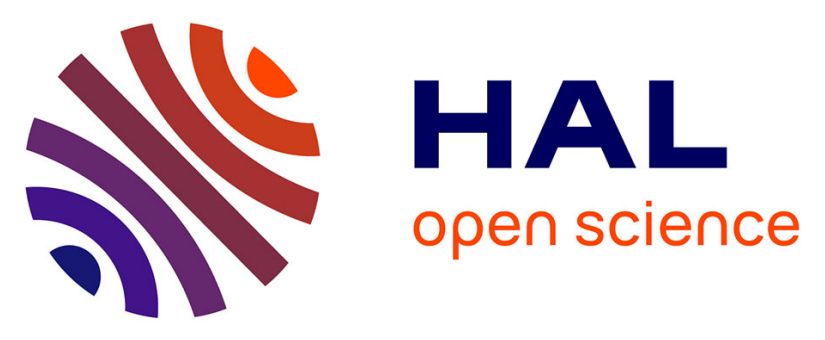

\title{
Solving the Challenging Synthesis of Highly Cytotoxic Silver Complexes bearing Sterically Hindered NHC Ligands with Mechanochemistry
}

Audrey Beillard, François Quintin, Jérémie Gatignol, Pascal Retailleau, Jean-Luc Renaud, Sylvain Gaillard, Thomas-Xavier Métro, Frédéric Lamaty, Xavier Bantreil

\section{To cite this version:}

Audrey Beillard, François Quintin, Jérémie Gatignol, Pascal Retailleau, Jean-Luc Renaud, et al.. Solving the Challenging Synthesis of Highly Cytotoxic Silver Complexes bearing Sterically Hindered NHC Ligands with Mechanochemistry. Dalton Transactions, 2020, 49 (36), pp.12592-12598. 10.1039/D0DT00410C . hal-02919846

\section{HAL Id: hal-02919846}

https://hal-normandie-univ.archives-ouvertes.fr/hal-02919846

Submitted on 19 Nov 2020

HAL is a multi-disciplinary open access archive for the deposit and dissemination of scientific research documents, whether they are published or not. The documents may come from teaching and research institutions in France or abroad, or from public or private research centers.
L'archive ouverte pluridisciplinaire HAL, est destinée au dépôt et à la diffusion de documents scientifiques de niveau recherche, publiés ou non, émanant des établissements d'enseignement et de recherche français ou étrangers, des laboratoires publics ou privés. 


\title{
Solving the Challenging Synthesis of Highly Cytotoxic Silver Complexes bearing Sterically Hindered NHC Ligands with Mechanochemistry
}

\begin{abstract}
Audrey Beillard, ${ }^{a}$ François Quintin, ${ }^{a}$ Jérémie Gatignol, ${ }^{b}$ Pascal Retailleau, ${ }^{c}$ Jean-Luc Renaud, ${ }^{\mathrm{b}}$ Sylvain Gaillard, ${ }^{*, b}$ Thomas-Xavier Métro, ${ }^{a}$ Frédéric Lamaty and Xavier Bantreil ${ }^{*, a}$

Dedicated to Professor Ei-ichi Negishi on the occasion of his 85th birthday

The use of ball-mills enabled the straightforward synthesis of a variety of silver(I) complexes featuring challenging NHC ligands. Sterically hindered including electron-poor or with very low solubility imidazolium salts were grinded with silver(I) oxide to furnish heteroleptic or homoleptic complexes in high yield and short reaction times. The synthesis of heteroleptic bis-NHC silver(I) complexes was also performed for the first time in a ball-mill. The efficiency and rapidity of the mechanochemical approach enabled the generation of a library of unprecedented NHC silver complexes, which cytotoxicity on HCT116 colorectal cancer cell line was evaluated providing a rare example of medicinal mechanochemistry. The cationic silver complexes were found more potent than the neutral analogues, with IC 50 values down to $21 \mathrm{nM}, 256$ times more potent than cisplatin.
\end{abstract}

\section{Introduction}

$\mathrm{N}$-heterocyclic carbenes (NHC) are widely used for the stabilization of transition metals, especially compared to phosphines in catalytic systems. ${ }^{1}$ Additionally, NHC-based complexes have found interest due to their biological properties, for example for their antibacterial, antifungal or anticancer properties. ${ }^{2}$ Besides, many groups have shown that NHC-gold(I) and NHC-gold(III) complexes could be valid alternatives to cisplatin due to their different mode of action. ${ }^{3}$ Silver(I) complexes have also been studied because they might behave similarly to gold complexes. ${ }^{2 a-e,} 4$ However, NHCsilver(I) complexes have mostly been studied for their antibacterial and antimicrobial activity, ${ }^{5}$ and only some of them were found to be active as anticancer agents. ${ }^{6}$ However, most of these complexes were either neutral $[\mathrm{AgCl}(\mathrm{NHC})]$ complexes or cationic homoleptic $\left[\mathrm{Ag}(\mathrm{NHC})_{2}\right]$ complexes featuring $\mathrm{N}, \mathrm{N}$-dialkyl ligands. Cationic homoleptic $\left[\mathrm{Ag}(\mathrm{NHC})_{2}\right]$ complexes bearing $\mathrm{N}, \mathrm{N}$-diaryl $\mathrm{NHC}$ ligands have been less studied because their synthesis is known to be more challenging. Yet, we recently developed a mechanochemical ${ }^{7}$ solvent-free method that enables a rapid and highly efficient access to such complexes. ${ }^{8}$ Additionally, ball-milling permits to easily synthesize neutral $[\mathrm{AgCl}(\mathrm{NHC})]$ complexes, either with alkyl or aryl substituents. ${ }^{9}$ In this manuscript, we initially focused our attention on the mechanosynthesis of less conventional silver complexes bearing sterically hindered $\mathrm{NHC}$ ligands including one with electron withdrawing groups, to assess if the mechanochemical approach could solve synthetic problems encountered in solution. ${ }^{7 g}$ Then, we evaluated the cytotoxicity of the corresponding complexes, as well as heteroleptic bis-NHC complexes, as anticancer agents on colorectal HCT116 cancer cell line. Of note, this represents one of the rare examples of mechanochemical synthesis of molecules for biological testing, a branch of medicinal mechanochemistry. ${ }^{10}$

\section{Results and discussion}

\section{Mechanosynthesis of heteroleptic neutral silver(I) complexes}

First, the synthesis of neutral heteroleptic complexes was realized by milling highly encumbered imidazolium salts 1a-e and silver(I) oxide in slight excess in a stainless steel jar containing a $1 \mathrm{~cm}$ diameter stainless steel ball, using a vibratory MM400 ball-mill (Scheme 1). Gratifyingly, after $3 \mathrm{~h}$ at $30 \mathrm{~Hz}$, full conversion was obtained in all cases. Complexes $\mathbf{2 a}$ and $\mathbf{2 b}$, featuring ligands IPrOMe (1,3-bis(4-methoxy-2,6diisopropylphenyl)imidazol-2-ylidene) and MeIPrOMe (1,3-bis(4methoxy-2,6-diisopropylphenyl)-4,5-dimethylimidazol-2ylidene) could be isolated in $81 \%$ and $86 \%$ yield, respectively. In solution, the use of electron poor ClIPr. $\mathrm{HCl}$ 1c $(1,3-$ bis(2,6diisopropylphenyl)-4,5-dichloroimidazolium chloride) revealed problematic. Indeed, even when full conversion was obtained, isolated yield of corresponding complex 2c did not exceed 

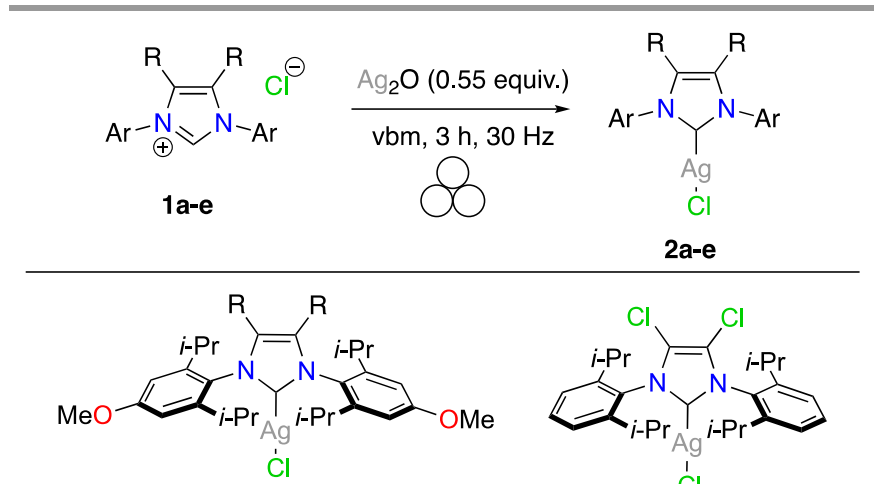

$\mathrm{R}=\mathrm{H}, \mathbf{2 a}, 81 \%$

$\mathrm{R}=\mathrm{Me}, \mathbf{2} \mathbf{b}, 86 \%$

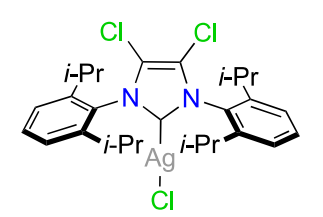

2c, $90 \%$

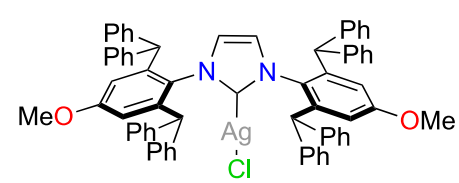

2d, $89 \%$

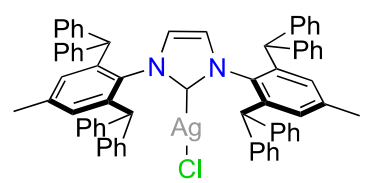

$2 e, 81 \%$
Scheme 1. Mechanosynthesis of $[\mathrm{AgCl}(\mathrm{NHC})]$ complexes bearing highly encumbered NHC ligands

$31 \% .{ }^{11}$ Of note, the same trend was observed in the synthesis of [CuCl(ClIPr)], with $40 \%$ being the highest reported isolated yield. ${ }^{12}$ Using the ball-mill, full conversion of $1 \mathrm{c}$ was also observed, but, in sharp contrast to the solution, upon treatment, complex $\mathbf{2 c}$ was isolated in an excellent $90 \%$ yield. Increased steric hindrance was not a limit to the method as complexes $\mathbf{2 d}$ and $\mathbf{2 e}$, featuring IPr*OMe ([1,3-bis(4-methoxy-2,6-diphenylmethyl)phenyl]imidazol-2-ylid ene $)^{13}$ and IPr* ([1,3-bis(4-methyl-2,6-diphenylmethyl)phenyl]imidazol-2-ylide ne $)^{14}$ ligands, were isolated in $89 \%$ and $81 \%$, respectively. While the exact reason for such positive results is not exactly known at the moment, this could be reasonably explained by a kinetic effect, in the absence of solvent, together with the efficient mixing of highly concentrated mixtures. It is important to highlight that the solvent-free method revealed highly practical in these cases since the imidazolium salts $\mathbf{1 d}$ and $\mathbf{1 e}$ are poorly soluble in organic solvents and water.

\section{Mechanosynthesis of homoleptic cationic silver(I) complexes}

We then turned our attention to unprecedented homoleptic $\left[\mathrm{Ag}(\mathrm{NHC})_{2}\right] \mathrm{PF}_{6}$ complexes. Imidazolium salts 1a-i were first converted into their $\mathrm{PF}_{6}$ counterpart 3a-i using either the classical method, which consists in solubilizing the chloride salt in water in the presence of $\mathrm{KPF}_{6}$ and recover the hexafluorophosphate salt that precipitates, or our previously reported solvent-free milling approach. ${ }^{8}$ This latter technique enabled the reduction of the quantity of $\mathrm{KPF}_{6}$ and water used, and was found to be particularly efficient for salt $1 \mathbf{e}$ that reacts poorly in water due to a reduced solubility. In the ball-mill, anion metathesis occurred in $30 \mathrm{~min}$ under solvent-free conditions. We first focused on the synthesis of complex $4 \mathbf{c}$,
Table 1. Comparison of methods for the synthesis of $\left[\mathrm{Ag}\left({ }^{\mathrm{C}} \mathrm{IPr}\right)_{2}\right] \mathrm{PF}_{6}{ }^{\text {a }}$

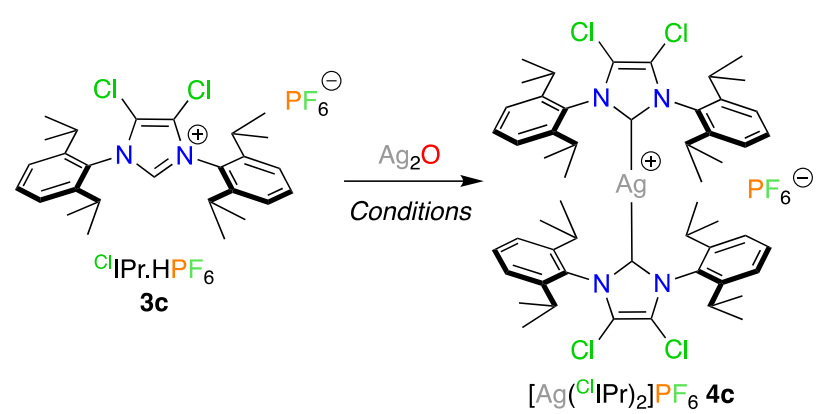

\begin{tabular}{cccc}
\hline Entry & Conditions & $\mathrm{t}(\mathrm{h})$ & Conv. $(\%)^{\mathrm{b}}$ \\
\hline 1 & $\mathrm{CHCl}_{3}$, reflux & 24 & 31 \\
& & 48 & 90 \\
2 & $\mathrm{NaOH}(1.1), \mathrm{CH}_{2} \mathrm{Cl}_{2}, \mathrm{rt}$ & 24 & $100(45)$ \\
3 & $\mathrm{NaOH}(1.1), \mathrm{vbm}, 30 \mathrm{~Hz}$ & 3 & $100(85)$ \\
\hline
\end{tabular}

a Reaction conditions: $3 c$ (0.15 mmol, 1 eq.), $\mathrm{Ag}_{2} \mathrm{O}$ (0.075 mmol, 0.5 eq.). b Conversion determined by ${ }^{1} \mathrm{H}$ NMR. Isolated yield is given in brackets.

featuring electron poor ClIPr ligand (Table 1). As discussed above, isolation of complexes featuring this ligand is difficult when the reaction is performed in solution. Reaction of $\mathbf{3 c}$ with

(a)

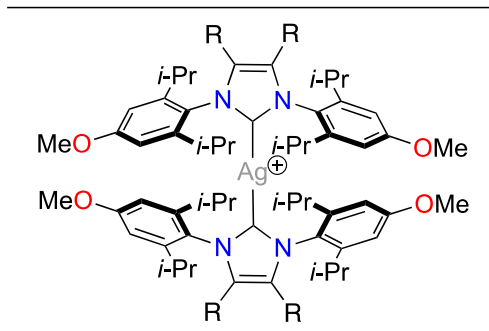

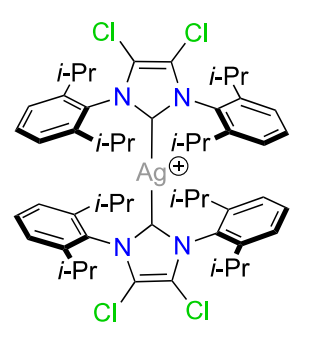

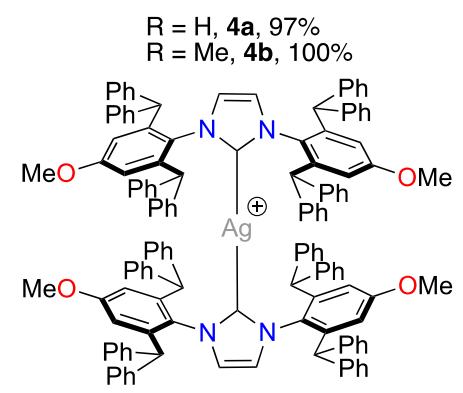

4d, $94 \%$

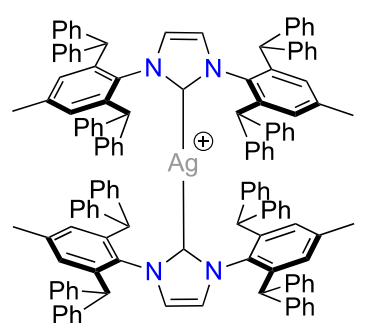

4 e, $93 \%$
Scheme 2. Mechanosynthesis of homoleptic $\left[\mathrm{Ag}(\mathrm{NHC})_{2}\right] \mathrm{PF}_{6}$ complexes bearing highly encumbered NHC ligands 
silver(I) oxide in refluxing chloroform gave only $31 \%$ NMR conversion after $24 \mathrm{~h}$, and $90 \%$ after $48 \mathrm{~h}$ (Table 1 , entry 1 ). In dichloromethane at room temperature, with the addition of sodium hydroxide, it was possible to obtain full conversion of ${ }^{C I}$ IPr. HPF $_{6} 3 \mathrm{c}$ in $24 \mathrm{~h}$ (Table 1, entry 2). However, after filtration on Celite ${ }^{\circledR}$ and evaporation, complex 4c was obtained in only $45 \%$ yield. When imidazolium salt $3 \mathrm{c}$ was ball-milled with $\mathrm{NaOH}$ and $\mathrm{Ag}_{2} \mathrm{O}$ under solvent-free conditions at $30 \mathrm{~Hz}$ for $3 \mathrm{~h}$, $100 \%$ conversion was also observed. More importantly, after the same treatment as when the reaction was performed in solution, homoleptic complex $\left[\mathrm{Ag}\left({ }^{\mathrm{Cl}} \mathrm{IPr}\right)_{2}\right] \mathrm{PF}_{6} \mathbf{4 c}$ was isolated in $85 \%$ yield (Table 1 , entry 3 ). The desired complex $4 \mathrm{c}$ may thus easily decompose in solution while the solvent-free approach gives a much faster access to the complex and in a two-fold higher isolated yield.

The mechanochemical approach was then applied to salts 3a-e in the presence of silver oxide and sodium hydroxide (Scheme 2). As for complexes $\mathbf{2 a - e}$, full conversion was observed in all cases in $\mathbf{3} \mathbf{h}$ of milling. Homoleptic complexes $\mathbf{4 a}$ and $\mathbf{4 b}$ were isolated in excellent yields. The milling method was then applied successfully to poorly soluble $\mathrm{IPr}^{* O M} \cdot \mathrm{HPF}_{6} \mathbf{3 d}$, and corresponding $\left[\mathrm{Ag}\left(\mathrm{IPr} * \mathrm{OMe}_{2}\right)_{2}\right] \mathrm{PF}_{6} \mathbf{4 d}$ was isolated in $94 \%$ yield. On the other hand, $\left[\mathrm{Ag}\left(\mathrm{IPr}^{*}\right)_{2}\right] \mathrm{PF}_{6} 4 \mathbf{e}$ revealed highly unstable compared to $\mathbf{4 d}$, probably because of the worse $\sigma$-donation of IPr* compared to IPr*OMe. 13, 15 ${ }^{1} \mathrm{H}$ NMR analysis showed the disappearance of the characteristic $\mathrm{C}-\mathrm{H}$ proton of the imidazolium salt $\mathbf{3 e}$, with the formation of corresponding complex $4 \mathbf{e}$. Due to a quick decomposition of $\mathbf{4 e}$, it was impossible to obtain ${ }^{13} \mathrm{C} N M R$ analysis of the pure compound. ${ }^{16}$ Nevertheless, solid-state HRMAS (high resolution magic angle spinning) ${ }^{13} \mathrm{C} N M R$ spectroscopy on a $600 \mathrm{MHz}$ spectrometer confirmed the formation of the complex with the appearance of the characteristic carbenic carbon signal of $4 \mathrm{e}$ at $182 \mathrm{ppm}$ (Figure 1). Of note, the expected doublets for the carbenic signal appear as a broad singlet in solid-state ${ }^{13} \mathrm{C} N M R$. The low stability of $\left[\mathrm{Ag}\left(\mathrm{IPr}^{*}\right)_{2}\right] \mathrm{PF}_{6} \mathbf{4 e}$ could explain the low yields when the reactions were performed in solution. Indeed, the best conversion obtained when the reaction was attempted in refluxing chloroform was $62 \%$ after $48 \mathrm{~h}$, yet along with

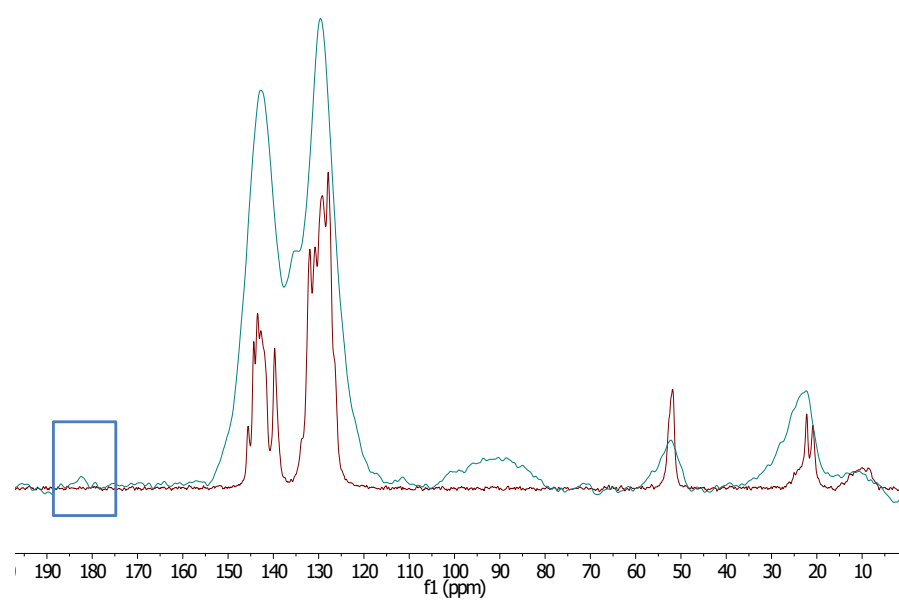

Figure $1 .{ }^{13} \mathrm{C}$ solid state HR-MAS NMR of IPr*.HPF 6 3e (red) and $\left[\mathrm{Ag}(\operatorname{IPr} *)_{2}\right] \mathrm{PF}_{6} 4 \mathbf{e}$ (blue)
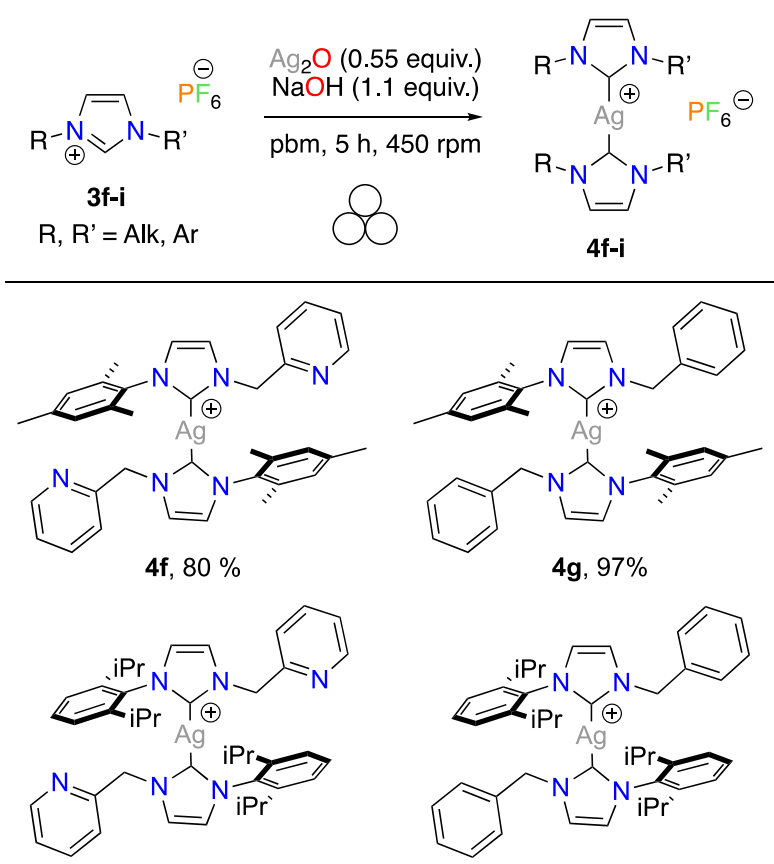

4h, $70 \%$

$4 i, 88 \%$

Scheme 3. Mechanosynthesis of homoleptic $\left[\mathrm{Ag}(\mathrm{NHC})_{2}\right] \mathrm{PF}_{6}$ complexes bearing $\mathrm{N}$-alkyl, $\mathrm{N}$-aryl ligands

important decomposition. ${ }^{16}$ Comparatively, complex $4 \mathbf{e}$ was isolated in $93 \%$ yield after $3 \mathrm{~h}$ of milling.

The synthesis of novel homoleptic complexes featuring $N$-alkyl, $\mathrm{N}$-aryl ligands was next performed (Scheme 3). Reaction of imidazolium salt $\mathbf{3 f}$, bearing a mesityl and a 2-picolyl group on the nitrogen atoms, was found to be slightly slower than with $\mathrm{N}, \mathrm{N}$-diaryl imidazolium salts 3 a-e, with $79 \%$ conversion after 3 $\mathrm{h}$ at $30 \mathrm{~Hz}$. Hence, reaction was performed using a planetary ball-mill, which is more adapted to longer reaction times. After $5 \mathrm{~h}$ at $450 \mathrm{rpm}$, full conversion was obtained, yielding complex $\mathbf{4 f}$ in $80 \%$. With a similar ligand bearing a benzyl instead of the 2-picolyl group, reaction proceeded efficiently and $\mathbf{4 g}$ was isolated in $97 \%$ yield. Increasing the steric hindrance on the aromatic ring with a 2,6-diisopropylphenyl group resulted in slightly lower yields of $70 \%$ and $88 \%$ for $\mathbf{4 h}$ and $\mathbf{4 i}$, respectively.

\section{Mechanosynthesis of heteroleptic cationic silver(I) complexes}

Finally, heteroleptic bis-NHC silver(I) complexes were synthesized using the vibratory ball-mill, starting from [AgCl(IPr)] 2f (IPr = 1,3-bis(2,6-diisopropylphenyl)-imidazol-2ylidene), which was prepared via mechanochemistry. ${ }^{9 b}$ To the best of our knowledge, the synthesis of heteroleptic silver(I) complexes was never attempted in a ball-mill. Reaction was thus first realized using classical IMes.HPF 6 (1,3-bis(2,4,6trimethylphenyl)imidazolium) and SIMes. HPF $_{6}$ (1,3-bis(2,4,6trimethylphenyl)imidazolinium) salts in the presence of sodium hydroxide (Scheme 4).

After $1 \mathrm{~h}$ of milling at $30 \mathrm{~Hz}$ in a vibratory ball-mill, full conversions were obtained and heteroleptic complexes 5a and $\mathbf{5 b}$ were isolated in $90 \%$ and $91 \%$ yield, respectively. Reaction with ClIPr.HPF 6 3c and MeIPrOMe. $\mathrm{HPF}_{6} \mathbf{3 b}$ yielded corresponding 

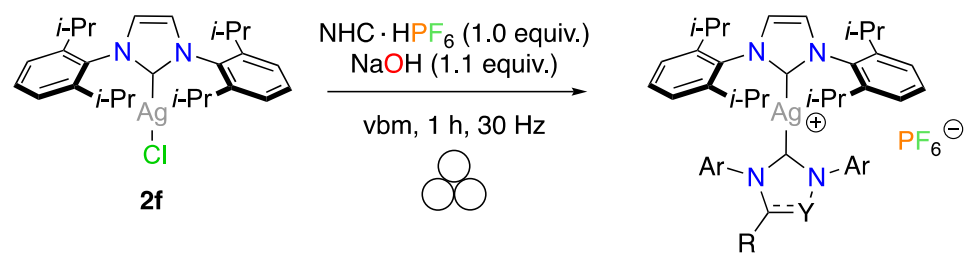

5a-f

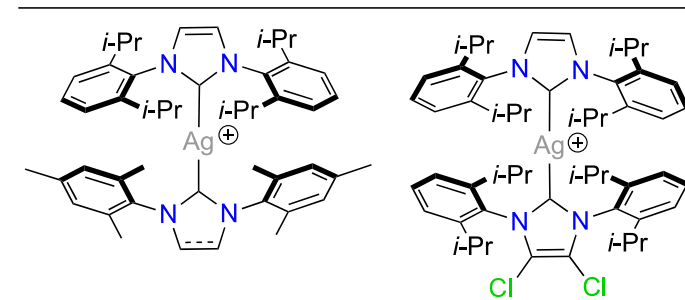

$5 c, 88 \%$

IMes, $\mathbf{5 a}, 90 \%$

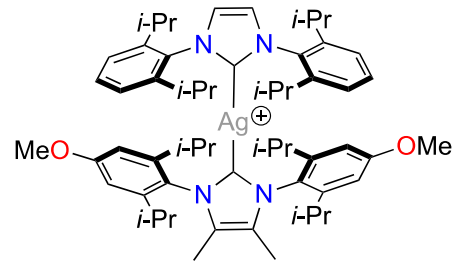

$5 d, 89 \%$ SIMes, $\mathbf{5 b}, 91 \%$
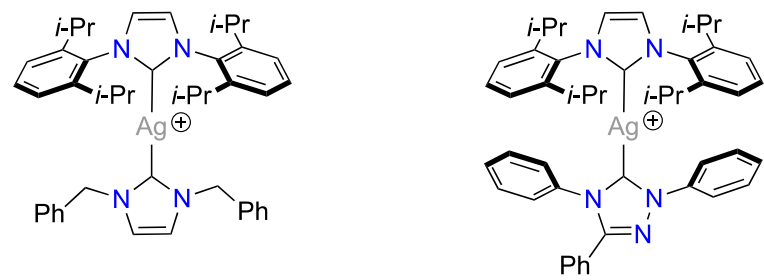

$5 e, 98 \%$

5f, $95 \%$

Scheme 4. Mechanosynthesis of cationic heteroleptic silver complexes

complexes $\mathbf{5 c}$ and $\mathbf{5 d}$ in $88 \%$ and $89 \%$, respectively. To widen the scope of attainable heteroleptic complexes using this methodology, $\mathrm{N}, \mathrm{N}$-dibenzylimidazolium hexafluorophosphate and TPT.HPF 6 (1,3,4-triphenyl-1,2,4-triazolium hexafluorophosphate) were reacted efficiently to furnish $\mathbf{5 e}$ and $\mathbf{5 f}$ in excellent yields. Of note, as shown by ${ }^{1} \mathrm{H}$ NMR and HRMS analyses, only traces of ligand scrambling, resulting in the formation of undesired homoleptic silver complexes, were observed. ${ }^{16}$

X-ray quality crystals could be grown by slow diffusion of diethyl ether into a dichloromethane solution of complexes $\mathbf{2 a}$,

Table 2. $\% V_{\text {bur }}$ for the different complexes

\begin{tabular}{ccccc}
\hline Entry & Complex & $\mathrm{d}_{\mathrm{C}-\mathrm{M}}(\AA)$ & \%Vbur $^{\mathrm{a}}$ & \%Vbur $^{\mathrm{b}}$ \\
\hline $\mathbf{1}$ & $\mathbf{2 a}$ & 2.080 & 40.2 & 41.3 \\
$\mathbf{2}$ & $\mathbf{2 b}$ & 2.087 & 42.8 & 42.5 \\
$\mathbf{3}$ & $\mathbf{2} \mathbf{e}^{14}$ & 2.078 & 52.9 & 52.9 \\
$\mathbf{4}$ & $\mathbf{4 a}$ & 2.099 & 38.7 & 38.7 \\
$\mathbf{5}$ & 4b & 2.122 & 40.2 & 40.7 \\
\hline
\end{tabular}

a \%Vbur calculated with real C-Ag distance, sphere radius of $3.5 \AA$. ${ }^{b}$ Distance C-Ag normalized at $2.1 \AA$, sphere radius $3.5 \AA$. a)

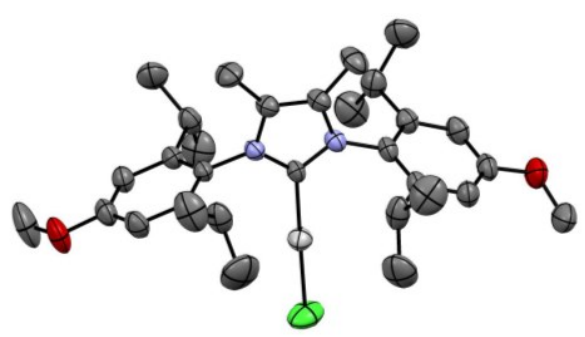

b)

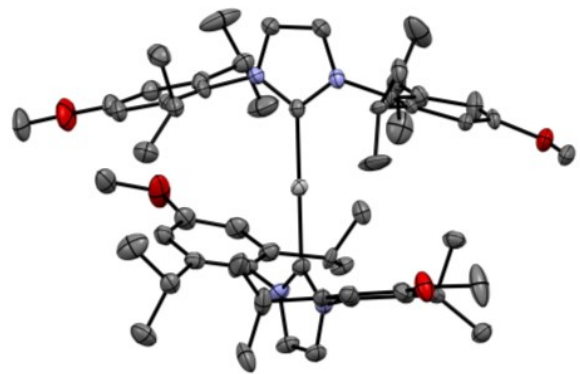

Figure 2. ORTEPs (at $50 \%$ probability level) of compounds (a) $\mathbf{2 b}$, (b) $\mathbf{4 a}$. Hydrogen atoms and $\mathrm{PF}_{6}$ anion are omitted for clarity.

2b, $\mathbf{4 a}$ and $\mathbf{4 b}$ (Figure 2). XRD analysis allowed to evaluate the steric properties of the ligands by calculating the $\% V_{\text {Bur }}$ (percent buried volume) of each complex using the SambVca web application (Table 2). ${ }^{17}$ As already witnessed with other metals, the introduction of methyl groups on the NHC backbone ( $\mathbf{2 a}$ vs $\mathbf{2} \mathbf{b}$ and $\mathbf{4 a}$ vs $\mathbf{4 b}$ ), which push the aromatic moieties towards the metal center, induces an increase in $\% V_{B u r}$ in each case. The increase of the sterical hindrance also 
results in a longer NHC-metal distance. In comparison, ligand IPr* was found to be extremely hindered as $\% V_{\text {Bur }}$ calculated for $2 \mathrm{e}$ reaches a value of 52.9 while the $\% V_{\text {Bur }}$ of the isopropyl analogues do not exceed the value of 42.8 .

\section{Cytotoxic activity of NHC silver(I) complexes}

Since homoleptic silver(I) complexes featuring benzimidazole ${ }^{6 f}$ or imidazopyridine-based ${ }^{6 j}$ NHC ligand have already shown promising activity against colorectal HCT116 cancer cell lines compared to 5-fluorouracil or cisplatin, respectively, the unique capacity of mechanochemistry to generate rapidly a library of NHC silver complexes (2a-5f) prompted us to evaluate their cytotoxicity against this cell line. ${ }^{16}$ The percentage inhibition of cell proliferation was firstly measured using $10^{-5}$ and $10^{-6} \mathrm{M}$ solutions of the complexes (Figure 3 ). Half growth inhibition concentration $\left(\mathrm{IC}_{50}\right)$ was then measured only for compounds that showed high percentage of inhibition at $10^{-6} \mathrm{M}$ (Figure 4). As a comparison, doxorubicin and cisplatin, which are commonly used to treat cancer, were evaluated on the same cancer cell line and possess IC $C_{50}$ of 810 $\mathrm{nM}$ and $5.37 \mu \mathrm{M}$, respectively. In addition, [AgCIIPr] $\mathbf{2 f}$ and $\left[\mathrm{Ag}(\mathrm{IPr})_{2}\right] \mathrm{PF}_{6} \mathbf{4} \mathbf{j}$ complexes were also tested to evaluate the influence of substitutions of the ligand on cytotoxicity. Among the neutral heteroleptic complexes $\mathbf{2 a - f}$, only $\mathbf{2} \mathbf{d}$ and $\mathbf{2 e}$ were found almost inactive. Such behavior could be assigned to the poor solubility of the complexes in DMSO. Complex 2a showed an $\mathrm{IC}_{50}$ of $259 \mathrm{nM}$. As a comparison, 2f, which contains the classical IPr ligand, exhibited an IC $\mathrm{I}_{50}$ of $390 \mathrm{nM}$, thus showing the positive influence of the methoxy groups on the NHC. The introduction of methyl group on the backbone of the $\mathrm{NHC}$ resulted in another positive effect as $\mathbf{2} \mathbf{b}$ was found to be active at $96.8 \mathrm{nM}$. On the other hand, $\mathbf{2 c}$, featuring chlorine atoms on the backbone of the NHC, displayed an $\mathrm{IC}_{50}$ of $616 \mathrm{nM}$. Cationic homoleptic complexes having $\mathrm{N}, \mathrm{N}$-diaryl NHC ligands $4 \mathrm{a}-\mathrm{C}$

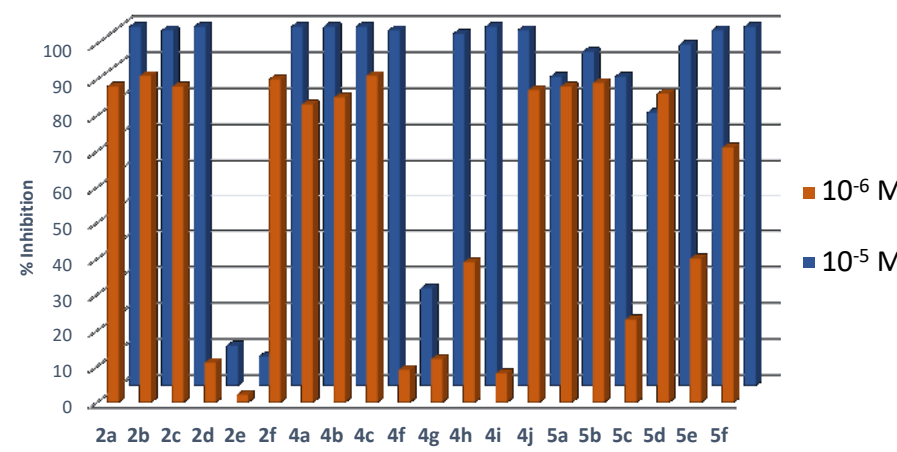

Figure 3. Percentage of inhibition against HCT116 carcinoma cells at $10^{-5}$ and $10^{-6} \mathrm{M}$

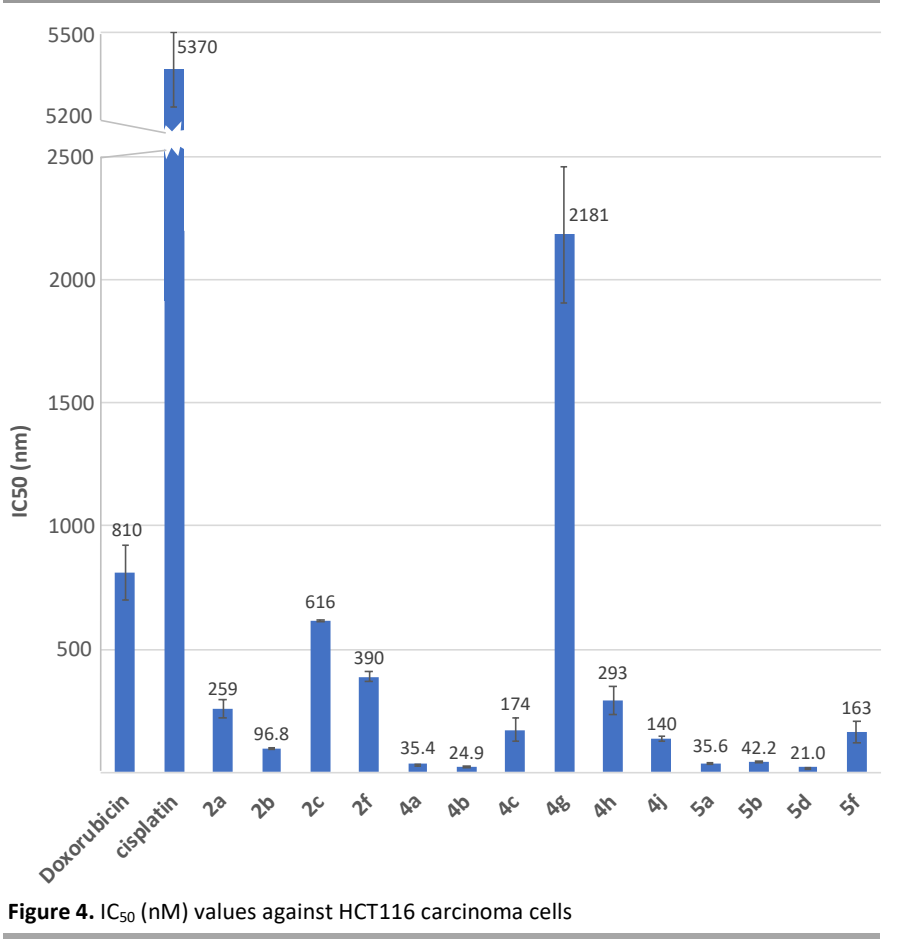

displayed a higher cytotoxicity, with $\mathrm{IC}_{50}$ values down to 24.9 $\mathrm{nM}$ for $\mathbf{4 b}$. Once again, the positive effect of the methoxy group was demonstrated as $\left[\mathrm{Ag}(\operatorname{IPr})_{2}\right] \mathrm{PF}_{6}$ complex displayed an $\mathrm{IC}_{50}$ of $140 \mathrm{nM}$ (vs $35.4 \mathrm{nM}$ for 4a). The addition of methyl groups on the NHC backbone results in even lower $\mathrm{IC}_{50}$ value (35.4 nM for 4a vs $24.9 \mathrm{nM}$ for $\mathbf{4 b}$ ). Homoleptic complexes $\mathbf{4 f - i}$, containing $\mathrm{N}$-aryl, $\mathrm{N}$-alkyl NHC ligands, were found to be less active. In this family, $\mathbf{4 h}$ was the most active, with an $\mathrm{IC}_{50}$ at 293 nM. Cationic bis-NHC silver complexes 5a-f also showed promising activity. 5a, featuring an IMes ligand, was more cytotoxic than $\mathbf{5 b}$ that contains the analogous saturated ligand. While very similar in structure, $\mathbf{5 d}$, having one IPr ligand in place of MeIPrOMe, was found to be slightly more active than homoleptic $\mathbf{4 b}$, with the best IC 50 of 21 nM. 5d is thus 256 and 38 times more active than cisplatin and doxorubicin, respectively. Interestingly, 5f, containing a TPT ligand, showed an $\mathrm{IC}_{50}$ of $163 \mathrm{nM}$, thus demonstrating a possible $10^{-6} \mathrm{M}$ diversification of the structure of the active complexes. On the other hand, $\mathbf{5 c}$ and $\mathbf{5 e}$, featuring a ClIPr and a $\mathrm{N}, \mathrm{N}$-dibenzyl $\mathrm{NHC}$ ligand, respectively, were not as active, with a \% inhibition of cell proliferation below the values obtained for the other complexes. Thus, this preliminary study shows that introducing chlorine atoms on the backbone of the NHC, or using $\mathrm{N}$-alkyl, $\mathrm{N}$-aryl NHC ligands is detrimental to the biological activity. In the case of complexes featuring chlorine-substituted NHC ligands, the lower activity could be due to instability issues, as observed during their synthesis in solution. On the other hand, the MeIPrOMe ligand, either in neutral heteroleptic or cationic complexes, seems to present the best positive effect on the cytotoxicity of the silver complexes. Of note, apart from $\mathbf{4 g}$, all the silver complexes tested displayed a higher cytotoxicity than doxorubicin and cisplatin. 


\section{Conclusions}

In conclusion, mechanochemistry overcame solution-based chemistry, permitting to access rapidly and efficiently novel families of neutral heteroleptic and cationic homo- and heteroleptic complexes featuring NHC ligands bearing sterically hindering groups, and also electron-donating or withdrawing substituents. Importantly, the use of ball-mills enabled the isolation of complexes difficult if not impossible to prepare and isolate using solution-based strategy. As most of the compounds obtained displayed a novel structure, their biological activity was evaluated. As preliminary results, the silver complexes showed high cytotoxic activity against colorectal HCT116 cancer cell line, with $\mathrm{IC}_{50}$ down to $21 \mathrm{nM}$, which is 256 times better than cisplatin.

\section{Conflicts of interest}

There are no conflicts to declare.

\section{Acknowledgements}

The Université de Montpellier, Centre Nationale de la Recherche Scientifique (CNRS) and Agence Nationale de la Recherche (grant no. ANR-16-CE07-0009-01) are acknowledged for funding. We thank Anthony Pinon and Marouan Lakhlil for their contribution to the design of the graphical abstract.

\section{Notes and references}

1. (a) S. Díez-González, N. Marion and S. P. Nolan, Chem. Rev. 2009, 109, 3612; (b) J. C. Y. Lin, R. T. W. Huang, C. S. Lee, A. Bhattacharyya, W. S. Hwang and I. J. B. Lin, Chem. Rev., 2009, 109, 3561.

2. (a) M.-L. Teyssot, A.-S. Jarrousse, M. Manin, A. Chevry, S. Roche, F. Norre, C. Beaudoin, L. Morel, D. Boyer, R. Mahiou and A. Gautier, Dalton Trans., 2009, 6894; (b) L. Mercs and M. Albrecht, Chem. Soc. Rev., 2010, 39, 1903; (c) A. Gautier and F. Cisnetti, Metallomics, 2012, 4, 23; (d) W. Liu and R. Gust, Chem. Soc. Rev., 2013, 42, 755; (e) L. Oehninger, R. Rubbiani and I. Ott, Dalton Trans., 2013, 42, 3269; (f) C. Hu, X. Li, W. Wang, R. Zhang and L. Deng, Curr. Med. Chem., 2014, 21, 1220; (g) W. Liu and R. Gust, Coord. Chem. Rev., 2016, 329, 191.

3. (a) F. Cisnetti and A. Gautier, Angew. Chem. Int. Ed., 2013, 52, 11976; (b) B. Bertrand and A. Casini, Dalton Trans., 2014, 43, 4209; (c) T. Zou, C. T. Lum, C.-N. Lok, J.-J. Zhang and C.-M. Che, Chem. Soc. Rev., 2015, 44, 8786; (d) J. Rieb, B. Dominelli, D. Mayer, C. Jandl, J. Drechsel, W. Heydenreuter, S. A. Sieber and F. E. Kuehn, Dalton Trans., 2017, 46, 2722; (e) M. Porchia, M. Pellei, M. Marinelli, F. Tisato, F. Del Bello and C. Santini, Eur. J. Med. Chem., 2018, 146, 709; (f) M. Mora, M. C. Gimeno and R. Visbal, Chem. Soc. Rev., 2019, 48, 447.

4. (a) S. B. Aher, P. N. Muskawar, K. Thenmozhi and P. R. Bhagat, Eur. J. Med. Chem., 2014, 81, 408; (b) H. A. Mohamed and C. E. Willans, Organomet. Chem., 2014, 39, 26; (c) N. A. Johnson, M. R. Southerland and W. J. Youngs, Molecules, 2017, 22, 1263/1; (d) S. Y. Hussaini, R. A. Haque and M. R. Razali, J. Organomet. Chem., 2019, $882,96$.
5. (a) L. Boubakri, K. Dridi, A. S. Al-Ayed, I. Ozdemir, S. Yasar and N. Hamdi, J. Coord. Chem., 2019, 72, 2080; (b) A. Mottais, M. Berchel, T. Le Gall, Y. Sibiril, F. d'Arbonneau, V. Laurent, P.-A. Jaffres and T. Montier, Int. J. Pharm., 2019, 567, 118500.

6. (a) L. Eloy, A.-S. Jarrousse, M.-L. Teyssot, A. Gautier, L. Morel, C. Jolivalt, T. Cresteil and S. Roland, ChemMedChem, 2012, 7, 805; (b) D. C. F. Monteiro, R. M. Phillips, B. D. Crossley, J. Fielden and C. E. Willans, Dalton Trans., 2012, 41, 3720; (c) S. Budagumpi, R. A. Haque, S. Endud, G. U. Rehman and A. W. Salman, Eur. J. Inorg. Chem., 2013, 4367; (d) M. A. Iqbal, R. A. Haque, M. B. K. Ahamed, A. M. S. A. Majid and S. S. Al-Rawi, Med. Chem. Res., 2013, 22, 2455; (e) M. A. Iqbal, R. A. Haque, S. Budagumpi, M. B. Khadeer Ahamed and A. M. S. Abdul Majid, Inorg. Chem. Commun., 2013, 28, 64; (f) R. A. Haque, S. Y. Choo, S. Budagumpi, M. A. Iqbal and A. Al-Ashraf Abdullah, Eur. J. Med. Chem., 2015, 90, 82; (g) A. H. Sandtorv, C. Leitch, S. L. Bedringaas, B. T. Gjertsen and H.-R. Bjørsvik, ChemMedChem, 2015, 10, 1522; (h) M. Asif, M. A. Iqbal, M. A. Hussein, C. E. Oon, R. A. Haque, M. B. Khadeer Ahamed, A. S. Abdul Majid and A. M. S. Abdul Majid, Eur. J. Med. Chem., 2016, 108, 177; (i) M. Marinelli, C. Santini and M. Pellei, Curr. Top. Med. Chem., 2016, 16, 2995; (j) L. Jhulki, P. Dutta, M. K. Santra, M. H. Cardoso, K. G. N. Oshiro, O. L. Franco, V. Bertolasi, A. A. Isab, C. W. Bielawski and J. Dinda, New J. Chem., 2018, 42, 13948; (k) S. Sahin-Bolukbasi and N. Sahin, J. Organomet. Chem., 2019, 891, 78.

7. (a) S. L. James, C. J. Adams, C. Bolm, D. Braga, P. Collier, T. Friščić, F. Grepioni, K. D. M. Harris, G. Hyett, W. Jones, A. Krebs, J. Mack, L. Maini, A. G. Orpen, I. P. Parkin, W. C. Shearouse, J. W. Steed and D. C. Waddell, Chem. Soc. Rev., 2012, 41, 413; (b) L. Takacs, Chem. Soc. Rev., 2013, 42, 7649; (c) G.-W. Wang, Chem. Soc. Rev., 2013, 42, 7668; (d) J. G. Hernández and T. Friščić, Tetrahedron Lett., 2015, 56, 4253; (e) N. R. Rightmire and T. P. Hanusa, Dalton Trans., 2016, 45, 2352; (f) J.-L. Do and T. Friščić, ACS Cent. Sci., 2017, 3, 13; (g) J. G. Hernández and C. Bolm, J. Org. Chem., 2017, 82, 4007; (h) J. Andersen and J. Mack, Green Chem., 2018, 20, 1435; (i) J. Howard, Q. Cao and D. L. Browne, Chem. Sci., 2018, 9, 3080; (j) D. Tan and T. Friščić, Eur. J. Org. Chem., 2018, 18; (k) A. Beillard, X. Bantreil, T.-X. Métro, J. Martinez and F. Lamaty, Chem. Rev., 2019, 119, 7529; (I) C. Bolm and J. G. Hernández, Angew. Chem. Int. Ed., 2019, 58, 3285; (m) C. M. Cova and R. Luque, BMC Chem. Eng., 2019, 1, 16; (n) D. Tan and F. García, Chem. Soc. Rev., 2019, 48, 2274; (o) T. Friščić, C. Mottillo and H. M. Titi, Angew. Chem. Int. Ed., 2020, 59, 1018.

8. A. Beillard, X. Bantreil, T.-X. Métro, J. Martinez and F. Lamaty, Dalton Trans., 2016, 45, 17859.

9. (a) A. Beillard, E. Golliard, V. Gillet, X. Bantreil, T.-X. Métro, J. Martinez and F. Lamaty, Chem. Eur. J., 2015, 21, 17614; (b) A. Beillard, X. Bantreil, T.-X. Métro, J. Martinez and F. Lamaty, New J. Chem., 2017, 41, 1057.

10. (a) D. Tan, L. Loots and T. Friscic, Chem. Commun., 2016, 52, 7760; (b) P. F. M. Oliveira, B. Guidetti, A. Chamayou, C. AndréBarrès, J. Madacki, J. Korduláková, G. Mori, B. S. Orena, L. R. Chiarelli, M. R. Pasca, C. Lherbet, C. Carayon, S. Massou, M. Baron and M. Baltas, Molecules, 2017, 22, 1457; (c) C. Tirapegui, W. Acevedo-Fuentes, P. Dahech, C. Torrent, P. Barrias, M. RojasPoblete and C. Mascayano, Bioorg. Med. Chem. Lett., 2017, 27, 1649; (d) B. Chakraborty, J. Heterocycl. Chem., 2019.

11. S. Gaillard, A. M. Z. Slawin, A. T. Bonura, E. D. Stevens and S. P. Nolan, Organometallics, 2010, 29, 394.

12. M. Elie, F. Sguerra, F. Di Meo, M. D. Weber, R. Marion, A. Grimault, J.-F. Lohier, A. Stallivieri, A. Brosseau, R. B. Pansu, J.-L. Renaud, M. Linares, M. Hamel, R. D. Costa and S. Gaillard, ACS Appl. Mater. Interfaces, 2016, 8, 14678. 
13. S. Meiries, K. Speck, D. B. Cordes, A. M. Z. Slawin and S. P. Nolan, Organometallics, 2013, 32, 330.

14. G. Berthon-Gelloz, M. A. Siegler, A. L. Spek, B. Tinant, J. N. H. Reek and I. E. Marko, Dalton Trans., 2010, 39, 1444.

15. (a) D. J. Nelson, A. Collado, S. Manzini, S. Meiries, A. M. Z. Slawin, D. B. Cordes and S. P. Nolan, Organometallics, 2014, 33, 2048; (b) H. V. Huynh, Chem. Rev., 2018, 118, 9457.

16. See Supporting Information for details.

17. (a) H. Clavier, A. Correa, L. Cavallo, E. C. Escudero-Adán, J. Benet-Buchholz, A. M. Z. Slawin and S. P. Nolan, Eur. J. Inorg. Chem., 2009, 1767; (b) A. Poater, B. Cosenza, A. Correa, S. Giudice, F. Ragone, V. Scarano and L. Cavallo, Eur. J. Inorg. Chem., 2009, 1759; (c) H. Clavier and S. P. Nolan, Chem. Commun., 2010, 46, 841. 